\title{
An initiative for integrating problem-based learning into a lean manufacturing course of an industrial engineering graduate program
}

\author{
Guilherme Tortorella $^{\mathrm{a} *}$, Paulo Augusto Cauchick-Miguel ${ }^{\mathrm{a}}$ \\ aUniversidade Federal de Santa Catarina, Florianópolis, SC, Brazil \\ *g.tortorella@ufsc.br
}

\begin{abstract}
The interest in improving the quality of engineering education is widely deemed. Due to an increasingly worldwide competition, Lean Manufacturing (LM) has been a relevant subject among industrial engineering graduate programs. Despite the advances in teaching LM principles and techniques, the practical character inherent to LM undermines learning and development of students. In this sense, this study aims at demonstrating a proposal to enhance LM learning in an industrial engineering program. It is a blended proposal that combines traditional teaching methods to problem-based learning (PBL) approach based on real problems of companies undergoing a lean implementation. A first phase of the proposal introduction is illustrated with an example of introducing it in a Brazilian federal university. The findings indicate that PBL may be an effective complementary method for LM learning, especially if graduate students are exposed to real problems in companies that are undergoing a lean implementation and related it to the current body of literature.
\end{abstract}

Keywords

Engineering education. Problem-based learning. Lean manufacturing.

How to cite this article: Tortorella, G., \& Cauchick-Miguel, P. A. (2017). An initiative for integrating problem-based learning into a lean manufacturing course of an industrial engineering graduate program. Production, 27(spe), e20162247. http://dx.doi.org/10.1590/0103-6513.224716

\section{Introduction}

A current challenge in education is determining how to present course material so that students not only gain knowledge, but also become self-directed learners who develop problem solving skills that can be applied in their careers (Sheppard et al., 2008; White, 2001). In this sense, problem-based learning (PBL) has been widely implemented (Jaeger \& Adair, 2014; Mantri, 2014; Warnock \& Mohammadi-Aragh, 2016; McCrum, 2016; Dahms et al., 2016). Thus, a better understanding of how PBL approaches may enhance learning is needed (Jones et al., 2013). In PBL courses, students work in teams to solve complex and authentic problems that enable developing content knowledge and problem-solving, reasoning, communication, and self-assessment skills. Moreover, the involvement with problem-solving also helps to keep students interest in course material, since students may realize that they are learning skills needed to be successful in the field (White, 2001; HmeloSilver, 2004; Dahms \& Stentoft, 2008).

A growing interest in using PBL in engineering education has been noticed in the past decades, which is aligned with current efforts to move from decontextualized presentation of technical content to holistic integration of content and practice (Sheppard et al., 2008). Despite an increasing of publications, few studies have provided systematic evidence of PBL (Galand et al., 2012; Jones et al., 2013). Moreover, the adoption of PBL in engineering education is usually adapted to existing program structures and outcomes, which may change the PBL approach from its roots in medical schools, and suggests a potential lack of PBL research in engineering education (Distlehorst et al., 2005; Bédard et al., 2012). 
Among the relevant subjects, Lean Manufacturing (LM) has been an emerging in industrial engineering graduate courses (Kanigolla et al., 2014; Conger \& Miller, 2014). LM is an organizational and systemic philosophy that aims to eliminate non-value added activities in order to offer a product or service with minimum cost and best quality according to customers' expectation (Liker, 2004; Womack \& Jones, 2009). The change from a traditional mass production model to a LM system entails not only technical aspects but also behavioral shifts that must be consistently practiced on a daily basis (Mann, 2014; Martins et al., 2016). Within the industrial engineering education, LM has been mainly approached by operations management, despite its inherent interfaces with other subjects, such as product development, logistics, and ergonomics (Stier, 2003; Alves et al., 2014).

Despite the advances in teaching LM principles and techniques, the exclusive utilization of traditional teaching methods undermine learning and development of graduate students due to LM's practical character. For instance, Conger \& Miller (2014) emphasize that many graduate students have little exposure to the principles and techniques of LM. Without a contextual basis on which to build, helping students to understand and apply LM and the corresponding skills outside the classroom becomes a challenge. It might also be frustrating to students who expect to directly transfer what they learned in class to their jobs' environment (Johnson et al., 2003; Conger \& Miller, 2013). Therefore, the lack of practical experience from students added by the single utilization of a traditional teaching method compels to a modification of teaching and learning styles in order to compensate such gaps.

In this sense, this work aims at demonstrating a proposal to enhance LM learning in industrial engineering graduate course. It is a blended proposal that combines traditional teaching methods with PBL approach based on real problems of companies undergoing a lean implementation. The effectiveness of the proposal would be assessed according to three levels of knowledge structure (Gijbels et al., 2005): ( $i$ ) understanding of principles, (ii) understanding of concepts, and (iii) application of concepts and principles. The aim is to implement the proposal in a Brazilian federal university, which was one of the precursors in teaching graduate industrial engineering courses in the country.

The contribution of this paper is two-fold. Firstly, based on the application of PBL as a complementary approach to a traditional LM teaching method, it bridges a gap between theory and actual practice of LM within industrial engineering education at a graduate level. The search and application of the proper LM knowledge to solve real problems reinforces the lean principles better than a classroom environment can do. Secondly, an assessment of the teaching methods effectiveness according to the knowledge structure allows verifying learning preferences and provides feedback for improving the suggested teaching style along the course.

Finally, the remainder of this paper is structured as follows. Section 2 gives a brief overview of the literature on PBL and teaching as well as learning about LM. Section 3 describes the proposal, from which its preliminary results of its application is presented in section 4 . Section 5 draws the main concluding remarks of this work and further work opportunities.

\section{Literature background}

\subsection{Problem-based learning}

Problem-based learning is one among several approaches in active learning. It is well-spread in engineering education. When searching for documents (in title, abstract and keywords) at Elsevier Scopus search service, 'engineering education' AND 'problem based learning' is one of the top three hits (Lima et al., 2017). It has been applied in undergraduate engineering education (Mantri, 2014; McCrum, 2016) and technical and professional skills (Warnock \& Mohammadi-Aragh, 2016). While the content and structure of PBL courses may differ according to context, the general goals and learning tend to be similar (Dahms \& Stentoft, 2008; Beddoes et al., 2010). PBL assumes that learning is an active, integrated and constructive process influenced by social and contextual factors (Dochy et al., 2003).

PBL is characterized as a student-centred approach, in which teachers are facilitators rather than disseminators, and open-ended problems serve as initial motivation and framework for learning. Students should identify their learning needs, lead class discussions, and assess their own work and teammates' work. Teacher perspectives in PBL environmental are relevant (Dahms et al., 2016) so it is the students' interest and ability (Jaeger \& Adair, 2014). Problems are designed to be complex, ill-structured, reflective of realistic practice, and framed to promote knowledge acquisition, problem-solving, self-directed learning, and interest (Hmelo-Silver, 2004; Santos \& Silva, 2015). Hitt (2010) complements that the activities carried out in a PBL approach must be those valued in the real world, and a close analysis and discussion of what has been learned from this problem are essential. 
Additionally, the emphasis on "learning by doing" entails that students must be conscious of what information is already known about the problem, which information they need to know to solve it and possible strategies to apply (Lonka et al., 2005; Strobel \& Van Barneveld, 2009). Through the articulation of such thoughts, students become more effective problem-solvers and self-directed learners. However, many students may struggle with this sort of thinking and, hence, teachers must change their approach and become cognitive coaches who model inquiry strategies, guide exploration and help clarify and pursue the research questions (Galand et al., 2012). Collaborative learning and facilitator support can contribute to students' success beliefs by allowing them to engage in mastery experiences. The reflective components of PBL can also contribute to higher levels of individual interest in helping students explicitly articulate their growing comprehension of the real work (Hasna, 2008; Bédard et al., 2012).

There are four main principles to a successful PBL approach (Barron et al., 1998): (i) learning appropriate goals, (ii) scaffolds that support both student and teacher learning, (iii) frequent opportunities for formative self-assessment and revision, and (iv) social organizations that promote participation and result in a sense of agency. Hasna (2008) state there are three roles for PBL: (i) acquisition of factual knowledge; (ii) mastery of general principles or concepts that can be transferred to solve similar problems; and (iii) acquisition of prior examples that can be used in future situations of similar nature. Abdalla \& Gaffar (2011) describe seven steps to PBL implementation: $(i)$ explore the issue, in which students gather necessary information, learn new concepts, principles, and skills about the proposed topic; (ii) state what is known, in which is performed a list of what students already know about the scenario and what areas they are lacking information; (iii) define the issues, which frames the problem in a context of what is already known and information the students expect to learn; (iv) research the knowledge in which students find resources and information that will help create a compelling argument; $(v)$ investigate solutions, in which students list possible actions and solutions to the problem, formulate and test potential hypotheses; $(\mathrm{V} i)$ present and support the chosen solution, clearly state and support their conclusion with relevant information and evidence; and (vii) review the performance, in which students must evaluate their performance and plan improvements for the next problem.

Within the engineering education context, the emergence of PBL dates back to the 1970s (Beddoes et al., 2010). Pioneered by a medicine course of the McMaster University in Canada, the movement toward the practice of PBL in the chemical engineering course at McMaster University was caused by three educational problems (Woods, 1996): (i) constant pressure to add specialized disciplines in an already overloaded curriculum; (ii) mismatch between the needs of industry and the profile of engineering graduates; and (iii) the need to shift the final responsibility for the education from the educational vision to the learning vision. Despite growing popularity, evidence on PBL efficacy is still scarce and contradictory (Galand et al., 2012). When comparing students from traditional and PBL medical curricula, Lonka et al. (2005) and Distlehorst et al. (2005) found out no significant differences in knowledge acquisition. On the other hand, Dahms \& Stentoft (2008) and Felder et al. (1998) reinforce the positive results of PBL application in the students' knowledge and problem-solving skills. One explanation for the contradictory findings has been provided by some researchers (Dochy et al., 2003; Strobel \& Van Barneveld, 2009), who suggest that PBL has a robust positive effect on knowledge application and a weaker effect in favor of knowledge acquisition, since knowledge application is more suitable to the kind of skills that PBL is supposed to foster.

Specifically in the case of Brazilian engineering education, this approach is relatively recent and limited research evidenced the application of PBL in engineering education. For instance, Campos et al. (2013) suggest a qualitative method to evaluate the utilization of PBL for graduate engineering students in order to identify critical success factors to improve learning. Silva Junior et al. (2013) assess the match between learning and teaching styles on a civil engineering course based on the application of ILS (Index of Learning Styles) and conceptual maps. Santos \& Silva (2015) evaluated 115 students' overall perceptions of PBL use in a computer engineering program through an application of a 32-item questionnaire. The study found that most of the students were satisfied with PBL and indicated a successful use of it in the program. Furthermore, the adoption of PBL may be an interesting educational alternative to raising the rate of training and professional qualification of Brazilian engineers, and making engineering courses more stimulating and attractive (Cavalcante \& Embiruçu, 2013).

\subsection{Teaching and learning of lean manufacturing}

According to Liker (2004), the four main principles of LM are: (i) long-term thinking philosophy; (ii) continuous process improvement to eliminate waste; (iii) people and partners respect, challenge and grow; and (iv) problem-solving by continuous improvement and learning. In this sense, learning at all levels of the organization is a key element in LM (Tortorella \& Fogliatto, 2014), being mainly developed based on a "learning 
by doing" system following a structured and scientific method. This learning system has been followed by many manufacturing and service companies that are under lean implementation, transforming employees in truly active thinkers and learners (Alves et al., 2012).

In terms of academic education, teaching LM principles and techniques to students has been considered imperative, due to the challenging and competitive scenario that most organizations currently face and, hence, demand from their workforce (Murman et al., 2007). Thus, LM has been integrated in a multidisciplinary way in several universities as part of the educational curricula, with special emphasis on engineering education (Alves et al., 2014). An example of such integration is the establishment of the LEAN (Lean Education Academic Network), which is a group of university educators seeking to promote lean education in USA academia through sharing of knowledge and teaching materials (Fliedner \& Mathieson, 2009). Alves et al. (2014) and Flumerfelt et al. (2014) introduced the concept of lean engineering education (LEE), as a systematic, student-centered and value-enhanced approach to educational service delivery that enables students to holistically meet, lead and shape industrial, individual and societal needs by integrating comprehension and application of tools and concepts of engineering fundamentals.

Traditional LM books and teaching methods rely heavily on manufacturing experience. However, over the past few years during which $\mathrm{LM}$ has been taught, the number of engineering students with manufacturing work experience decreased (Johnson et al., 2003). Conger \& Miller (2013) state that the isolated application of one teaching method, e.g. teaching case studies, might be a poor choice for teaching LM, since students may lack both the physical and conceptual foundation of knowledge. In addition, there are other fundamental skills necessary to real LM implementation that are difficult to be taught from a book. There are several reports of lean programs and courses that use different teaching methodologies, such as classroom and guest lectures, virtual and game simulations, analysis of teaching case studies, plant tours, interviews with experts, etc. (Murman et al., 2007; Wan et al., 2012; Conger \& Miller, 2014; Kanigolla et al., 2014).

With regard to PBL utilization for teaching and learning of LM, few studies evidence its application under specific contexts. Stier (2003) presents an integrated teaching approach that combines PBL and simulation in order to provide students an adequate LM knowledge and skills. Conger \& Miller (2014) complement this approach by illustrating how lego exercises, when coupled with PBL, provide a useful framework for students to transfer their knowledge from the classroom to a lean six sigma project. Tovar \& Warshawsky (2015) expand the discussion by introducing a PBL exercise to teach LM principles and techniques to other courses than engineering. Specifically, the authors describe PBL application with nursing doctoral graduates to work through the quality improvement process using the lean 8-step problem-solving method. In terms of PBL effectiveness, Kanigolla et al. (2014) determined the importance of PBL on students' knowledge of LM through a survey that was carried out with students' teams after completion of hands-on collaborative projects. Their findings indicate a positive impact of PBL approach on the graduating students' knowledge, which was categorized in accordance with three knowledge areas: learning, critical thinking, and engagement.

Having presented a brief literature background of the main subjects, attention is turned to describing the structure of the proposal in this paper.

\section{Methodological structure of the proposal}

As earlier mentioned, this proposal tries to merge traditional LM teaching methods to PBL approach applied in real problems from companies undergoing a lean implementation, in order to complement and reinforce the three levels of knowledge structure proposed by Gijbels et al. (2005). This proposal presents characteristics of an action-research methodological approach (see Coughlan \& Coghlan, 2002), because the main idea is to implement a proposal in a graduate industrial engineering program. Nevertheless, the whole action-research cycle of implementation was not fully employed due to the characteristics of this work, in the subject of engineering education and, not necessarily, research-based.

The structure of the proposal consists of five main stages: $(i)$ understanding LM principles and its systemic thinking within organizations; (ii) definition of shop floor practices and operational concepts of a LM system; (iii) application of the previous knowledge in real problem solving situations of companies undergoing a lean implementation according to a PBL approach; (iv) assessment of students ILS profile; and $(v)$ triangulation among ILS profiles, teaching methods and student performance. The first three stages define the scope of three complementary and concurrent courses for teaching and learning LM of the graduate program in industrial engineering. Steps 4 and 5 provide tools for 'effectiveness assessment'. Table 1 summarizes the five stages of the proposal, which are more detailed next. 
Table 1. Steps of the proposal.

\begin{tabular}{|c|c|c|c|c|}
\hline Step & Description & Objective & Teaching method & $\begin{array}{c}\text { Evaluation method and } \\
\text { weight }\end{array}$ \\
\hline \multirow{4}{*}{1} & \multirow{4}{*}{$\begin{array}{c}\text { Course: LM Systemic } \\
\text { thinking and principles } \\
\left(\text { ( } 5 \mathrm{~T}^{\mathrm{T}} \text { Quarter }\right)\end{array}$} & \multirow{4}{*}{$\begin{array}{l}\text { Understanding of principles } \\
\text { that link concepts of LM }\end{array}$} & Classroom lectures; & $\begin{array}{c}\text { Classroom participation } \\
(20 \%)\end{array}$ \\
\hline & & & Inquiry learning; & Four short tests $(80 \%)$ \\
\hline & & & Team exercises and group participation; & \\
\hline & & & Case studies and short games. & \\
\hline \multirow{4}{*}{2} & \multirow{4}{*}{$\begin{array}{l}\text { Course: LM Shop } \\
\text { floor practices and } \\
\text { operational concepts } \\
\left(2^{\mathrm{ND}} \text { Quarter }\right)\end{array}$} & \multirow{4}{*}{$\begin{array}{l}\text { Understanding of concepts } \\
\text { of } \mathrm{LM}\end{array}$} & Analysis of case studies; & $\begin{array}{l}\text { Classroom participation } \\
(40 \%) ;\end{array}$ \\
\hline & & & Plant tours and visits in manufacturing facilities; & Final test $(60 \%)$ \\
\hline & & & Expert guest lectures; & \\
\hline & & & Lecture and lab exercises. & \\
\hline \multirow[t]{3}{*}{3} & \multirow{3}{*}{$\begin{array}{l}\text { Course: } \mathrm{LM} \text { PBL in } \\
\text { companies undergoing } \\
\text { lean implementation } \\
\left(3^{\mathrm{RD}} \text { Quarter }\right)\end{array}$} & \multirow{3}{*}{$\begin{array}{l}\text { Linking of concepts and } \\
\text { principles to conditions and } \\
\text { procedures for application } \\
\text { of } \mathrm{LM}\end{array}$} & $\begin{array}{l}\text { Problem-based learning techniques (LM } \\
\text { hypothetical problems, real problems on LM } \\
\text { implementation: visit in loco to find out real } \\
\text { problems, collect data and address solutions); }\end{array}$ & Presentation of A3 report: \\
\hline & & & Coaching and mentoring; & Lecturer/instructor (60\%) \\
\hline & & & Hands-on activities. & Team supervisor $(40 \%)$ \\
\hline 4 & $\begin{array}{l}\text { ILS application with } \\
\text { graduate students }\end{array}$ & $\begin{array}{c}\text { Verify the learning preferences } \\
\text { of each student }\end{array}$ & n.a. & n.a. \\
\hline 5 & Triangulation of results & $\begin{array}{l}\text { Verify the effectiveness of the } \\
\text { teaching and learning of } \mathrm{LM} \\
\text { through a comparison of the } \\
\text { ILS profiles, teaching methods } \\
\text { and students performance }\end{array}$ & n.a. & n.a. \\
\hline
\end{tabular}

The stage 1 aims at emphasizing the first level of knowledge structure denoted as "understanding of principles that link concepts". In this step, the instructor/lecturer teaches about the principles and the systemic thinking inherent to the LM implementation (as in Liker, 2004; Womack \& Jones, 2009) during the first quarter of the academic calendar. To achieve that, this first discipline is approached according to four main teaching methods based on suggestions by previous research: (i) classroom lectures (Miles \& Hawks, 2006), (ii) inquiry learning (Hall \& Holloway, 2008), (iii) team exercises and group participation (Johnson, 2010), and (iv) teaching case studies and short games (Murman et al., 2007). With regard to the grades, besides the classroom participation (20\% of the final grade), students are supposed to take four short tests distributed along the course that assess their understanding of the theoretical aspects of the LM principles (80\% of final grade).

The second stage conceptualizes the main LM shop floor and operational practices, such as (Shah \& Ward, 2007): total productive maintenance, single-minute exchange of die (SMED), 5S, visual management, pull system, etc. This course is planned for the second quarter of the academic calendar. It is focused on second level of knowledge structure named 'understanding of concepts'. The teaching method encompasses four complementary methods that have been previously recommended for achieving this kind of objective: $(i)$ analysis of teaching case studies (Torres \& Stephens, 2005), (ii) plant tours and visits in manufacturing facilities (Hall \& Holloway, 2008), (iii) expert guest lectures (Fang et al., 2006), and (iv) lecture and lab exercises (Johnson et al., 2003). Students' evaluation is based on activities performed in class ( $40 \%$ of final grade), and a final test that consolidates all subjects exposed during the discipline (60\% of final grade).

In the third stage, the PBL approach proposed by Abdalla \& Gaffar (2011) is integrated to the other traditional teaching methods, such as coaching and mentoring (Shook, 2008) and hands-on activities (Peter, 2010), in order to support and reinforce the third level of knowledge structure, which is "linking of concepts and principles to conditions and procedures for application'. This course is designed to be hold in a manufacturing facility of a company that has already started to implement LM practices and principles. Therefore, graduate students must develop their problem-solving and interpersonal skills under real-problem situations, which enhances the teams' responsibility and explains the importance of having the two previous stages as prerequisites for taking this course. During the PBL approach, besides the university lecturer acting as a coach or tutor, each team is supposed to have a company's senior manager as a team supervisor, whose role is to facilitate certain activities within the company and also evaluate students' performance along the problem-solving development. This supervisor is an experienced manager that has been implementing LM for at least five years, in order to ensure that he is familiar with LM practices and principles and also an expert in the company processes. At the end of the course, students must present an A3 report with the problem-solving description (see Tortorella et al., 2015), and the 
final grade of each student is a composition of the lecturer evaluation (60\% of the final grade) in addition to the supervisor (40\% of the final grade). This is based on five different competences' criteria (Bédard et al., 2012): (i) 'knowledge' - denotes maturity and complexity of acquired knowledge; (ii) 'analysis' - explains the capacity of subdividing the information into smaller parts and to detect relationships of one part to another and to all; (iii) 'application' - consists of the ability to apply learning to new situations and real life circumstances; (iv) 'comprehension' - understood as the ability to explain and translate for his own words; and ( $v$ ) 'synthesis' - denoted as the ability to bring together separate parts to form a whole new.

The stage 4 adapts and applies the ILS questionnaire with the graduate students in order to verify the preferred learning style, based on Felder \& Soloman (2004). The data are collected through the questionnaire by the lectures. The learning styles are preferred ways of organizing what one sees, remembers, and thinks about it. Thus, a student learning style profile provides an indication of probable strengths and possible tendencies or habits that might lead to difficulty in academic settings (Felder \& Silverman, 1988). The ILS is an instrument, consisted by 44 questions (Appendix A), used to assess preferences in four dimensions of a learning style: (i) information processing (active/reflective), (ii) information perception (sensing/intuitive), (iii) information input (visual/verbal), and (iv) information comprehension (sequential/global). The questionnaire results simply point out preferences for each dimension, and the suggestions that follow the results may enable to verify a match with the teaching method and assess its effectiveness, as showed in Figure 1. Three main outputs are indicated from the ILS application. If the student's final score is between 1 and 3, it denotes a preference fairly well balanced on the two styles of that scale. If scores are between 5 and 7, then the student may have a moderate preference for one style of the scale and will learn more easily in a teaching environment which favors that style. Finally, for scores between 9 and 11, the student has a very strong preference for one style of the scale, entailing in strong difficulty of learning in an environment which does not support that preference (Felder et al., 1998).

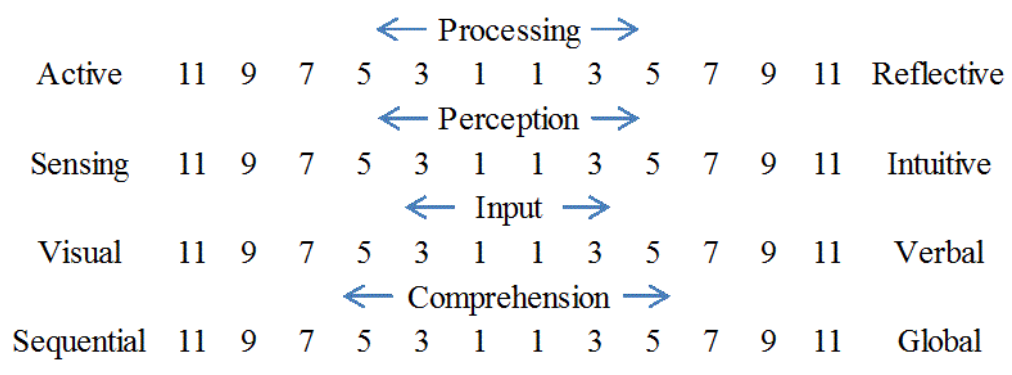

Scores interpretation:

- 1 to 3 : fairly well balanced between dimensions

- 5 to 7 : moderate preference for one dimension

- 9 to 11: very strong preference for one dimension

Figure 1. Schematic representation of ILS scale. Adapted from Felder \& Soloman, 2004.

Finally, the stage 5 consists of results triangulation in order to verify the potential matches among the designed teaching methods, the ILS profiles, and students' performance in each course. This stage allows examining if there are any learning preferences that are more suitable to one or more teaching method. Furthermore, through the students' performance evaluation in each course it is possible to understand how these methods complement each other during the learning of LM principles and concepts, according to the three levels of knowledge structure, earlier mentioned. Finally, the identification of learning gaps is also feasible through the triangulation of the results providing improvement feedbacks to this proposal.

The next section presents the first round of results since this is still a long term working in progress.

\section{First round of results}

The proposal was applied in a Brazilian public (federal) university, which was one of the precursors in teaching industrial engineering in Brazil at graduate level (it is the fourth master program in industrial engineering, established in 1969). The graduate program now offers both doctorate and master degrees, and 
receives approximately 200 applications per year in four research areas: operations management, ergonomics, product development, and logistics. Each research area has its own course portfolio, which are divided into three quarters within a year, starting in March, June, and September (finishing in the beginning of December). Since the implementation of this proposal is in progress, the results have not been fully concluded. Figure 2 shows the courses along the academic calendar. The figure refers to the lean manufacturing courses within the context of operations management.

Table 2. Students profile in the first course.

\begin{tabular}{cccccc}
\hline \multirow{2}{*}{ Degree application } & \multicolumn{2}{c}{ Previous experience with LM? } & \multicolumn{2}{c}{ Student dedication } \\
\cline { 2 - 3 } \cline { 5 - 6 } & No & Yes & Full time & 2 & Part time \\
\hline Doctoral & 1 & 3 & 2 & 5 \\
Master & 9 & 2 & 5 & 7 & 8 \\
Total & 10 & 5 & & 7 & 2 \\
\hline
\end{tabular}

$(\mathrm{n}=15)$.

The available teaching time within each quarter totalizes 48 hours, distributed over twelve weeks with one four-hour meeting per week. In the past, research on in LM has been mainly developed by the operations management; only one course directly related to LM has been offered during the academic calendar. During 2015, 15 graduate students (4 doctoral and 11 master degrees) started their research in LM and, thus, they were invited to participate during the whole deployment of this proposal. From those, only 5 students had previous experience with LM and 7 were full time students of the program, as shown in Table 2 .

Initially, the three courses proposed in stages 1,2, and 3 had their contents and subjects adapted to the teaching method and to the emphasis on the level of knowledge structure, as showed in Figure 2. The definition of those contents was elaborated by the 3 lecturers who have been involved with LM for at least 15 years (research and implementation). Moreover, several widely deemed books were used as reference to establish and divide the main topics of each discipline (e.g. Shingo, 1996; Rother \& Shook, 2003; Liker, 2004; Shook, 2008; Womack \& Jones, 2009; Duggan, 2012; Mann, 2014). Due to time restrictions, not all principles and practices were possible to be included in the courses. Nevertheless, three LM experts with significant practical background (engineers with a minimum of 20 years of experience) were asked to assess the contents of the courses to verify its consistency with practical needs and assisted the faculty to prioritize the main subjects to be delivered.

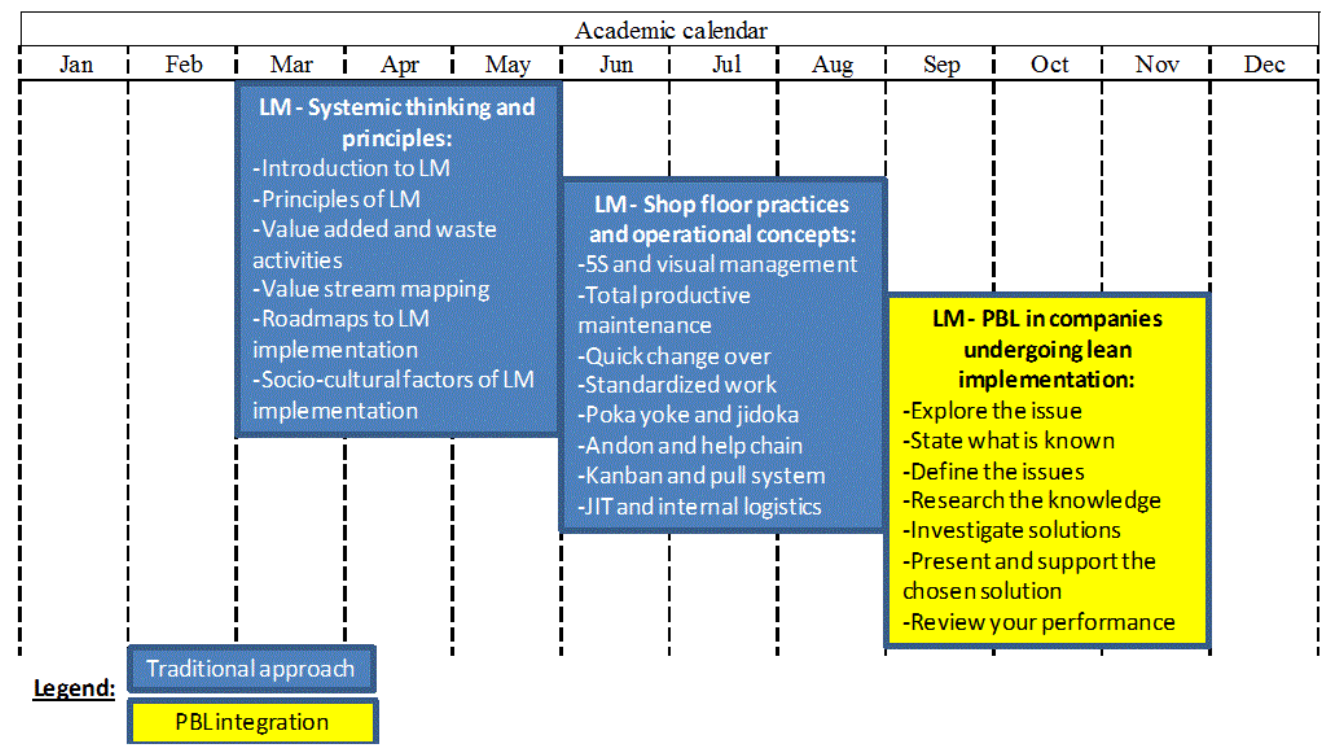

Figure 2. Courses in the proposal and their main contents.

When writing this manuscript, the first course 'LM systemic thinking and principles' was in progress during the first quarter. It focused on the level of understanding of principles, by consisting of six main topics: $(i)$ introduction to $\mathrm{LM}$, (ii) principles of LM, (iii) value added and waste activities, (iv) value stream mapping, ( $v$ ) roadmaps for LM implementation, and ( $v i)$ socio-cultural factors of LM implementation. During the 12 weeks that embraced 
the course, the four proposed teaching methods (see Table 1) were used interchangeably to expose and teach the contents. Regarding the evaluation method, the four short tests planned for this discipline were distributed according to six topics: test 1 (topics $i$ and $i$ ), test 2 (topics iii and $i$ ), test 3 (topic $v$ ), and test 4 (topic vi).

The second course 'LM - Practices, principles and concepts', focused on the level of understanding of principles and concepts of LM, to be offered in the second quarter of the university's academic calendar (June to August). The subjects were defined in order to cover the main principles, practices and concepts of three elements of the Toyota's house: basic stability, just-in-time, and jidoka (Liker \& Meier, 2006). With regard to basic stability, the practices $5 \mathrm{~S}$ and visual management, total productive maintenance (TPM), quick change over, and standardized work were included as part of the content. Just-in-time (JIT) involved the conceptualization of kanban and pull system practices, as well as material internal logistics. Finally, for jidoka, practices of poka yoke, andon, and help chain were selected.

The topics of the third-quarter course ('LM - PBL in companies undergoing lean implementation') integrated the PBL approach in a large auto parts manufacturer that is undergoing a lean implementation. Its purpose is to link the concepts and principles to conditions and procedures for an application of LM. The auto parts company has been implementing LM for 10 years and accepted to cooperate with the graduate program by opening its site to the students and providing the required structure to develop the course. The students would be divided into four or five teams assigned different ill-structured problems previously agreed between the lecturer and the respective company supervisor. From the twelve meetings scheduled for the course, one meeting aimed at introducing its contents and methods to students, seven meetings are to be hold inside the company for problem-solving activities and data collection, three in the university for direct orientation and coaching with the lecturer, and one final meeting for teams to present their performance to the lecture and the company's senior management team in an A3 report.

First round results from the ILS application are shown in Table 3. The table shows the results of application with students considering a perception of them accordingly to each dimension of assessment.

Regarding information processing, more than half of students' preferences is 'fairly well balanced' between an active and reflective profile. However, none of the students presented a 'moderate' or 'strong' preference for the reflective style, indicating that the remainder tend to retain and understand information best by doing something active with it, i.e. by discussing or applying it or explaining it to others. Results for information perception show that almost half of the students are well balanced between the sensing and intuitive styles. Despite this fact, one third of them 'moderately' and 'strongly' (13.33\% and 20\%, respectively) prefer the sensing style. This may denote that students like learning facts and solving problems using well-established methods while a bit more than 10\% present a moderate preference for discovering possibilities and relationships (intuitive style). For information input, results show that most students remember best what they see (visual learners), and only a minority of them gets more out of words (verbal learners), either written or spoken explanation. Finally, with regard to information comprehension, two third of students are fairly well balanced between the sequential and global styles. Furthermore, about 10\% 'moderately' prefer learning in large jumps, needing to see a wider perspective (the big picture) of a subject before they can master details (global learners). The remaining students seem to better understand the subjects through a linear approach, with each step following logically from the previous one (sequential learners). The next section draws some conclusions for the work carried out so far.

Table 3. Results of ILS profiles.

\begin{tabular}{lcccr}
\hline \multicolumn{1}{c}{ Dimensions } & & 'Fairly well balanced' & 'Moderate preference' & 'Strong preference' \\
\hline \multirow{2}{*}{ Information processing } & Active & \multirow{2}{*}{$60.00 \%$} & $33.33 \%$ & $6.67 \%$ \\
& Reflective & & $0.00 \%$ & $0.00 \%$ \\
\hline \multirow{2}{*}{ Information perception } & Sensing & \multirow{2}{*}{$46.67 \%$} & $20.00 \%$ & $20.00 \%$ \\
\hline \multirow{2}{*}{ Information input } & Intuitive & \multirow{2}{*}{$20.00 \%$} & $13.33 \%$ & $0.00 \%$ \\
\hline Information comprehension & Visual & & $46.67 \%$ & $20.00 \%$ \\
\hline
\end{tabular}

Source: results based on the number of students cited in Table $2(n=15)$.

\section{Conclusions}

The pedagogical environment in most of the graduate engineering programs still remains predominantly instructivist, regardless of the course. Traditional instructional methods view students as passive recipients, in which educational professionals are supposed to teach and students to learn. The application of PBL provides 
intellectual maturity and encourages interpersonal skills development so that students become independent learners.

A graduate program that applies a hybrid mode in which the early part of the courses is taught in a traditional setting to lay the fundamental concepts followed by a culminating period that provides an opportunity to extend the acquired knowledge into real and practical problems may be a better solution to enhance LM learning. The proper educational approach for teaching and learning of LM would help enhancing students' capability for acquiring and applying knowledge in real-world situations, preparing them to meet the required competences that fulfill either organizations or academia current demands. Therefore, providing engineering students with knowledge and practical experience of LM principles and techniques, and the ability to solve real problems gives employers a workforce with the necessary skill sets while making graduate students more marketable.

\section{References}

Abdalla, M., \& Gaffar, A. (2011). The seven steps of PBL implementation: tutor's manual (Blueprints in Health Profession Education Series). Jazan: Blueprints.

Alves, A., Dinis-Carvalho, J., \& Sousa, R. (2012). Lean production as promoter of thinkers to achieve companies' agility. The Learning Organization, 19(3), 219-237. http://dx.doi.org/10.1108/09696471211219930.

Alves, A., Kahlen, F., Flumerfelt, S., \& Manalang, A. (2014). The lean production multidisciplinary: from operations to education. In Proceedings of the 7th International Conference on Production Research Americas', Lima, Peru.

Barron, B., Schwartz, D., Vye, N., Moore, A., Petrosino, A., Zech, L., \& Bransford, J. (1998). Doing with understanding: lessons from research on problem- and project-based learning. Journal of the Learning Sciences, 7(3-4), 271-311. http://dx.doi.org/10.1080/1 0508406.1998.9672056.

Bédard, D., Lison, C., Dalle, D., Côté, D., \& Boutin, N. (2012). Problem-based and project-based learning in engineering and medicine: determinants of students' engagement and persistance. Interdisciplinary Journal of Problem-Based Learning, 6(2), 7-30. http:// dx.doi.org/10.7771/1541-5015.1355.

Beddoes, K., Jesiek, B., \& Borrego, M. (2010). ldentifying opportunities for collaboration in international engineering education research on problem- and project-based learning. Interdisciplinary Journal of Problem-Based Learning, 6(2), 7-34.

Campos, L., Lima, R., Alves, A., Mesquita, D., Moreira, F., \& Campos, B. (2013). Fatores críticos num processo de aprendizagem baseada em projetos: percepções de estudantes de $1^{\circ}$ ano de engenharia. São Paulo: Pontifical Catholic University of São Paulo.

Cavalcante, F., \& Embiruçu, M. (2013). Problem based learning: bringing enthusiasm to the classroom and decreasing dropout among engineering students. In Proceedings of the XLI Congresso Brasileiro de Ensino de Engenharia, Gramado, Brazil.

Conger, S., \& Miller, R. (2013). Problem-based learning for a lean six sigma course. Working Papers on Information Systems, 13(1), 1-9.

Conger, S., \& Miller, R. (2014). Problem-based learning applied to student consulting in a lean production course. Journal of Higher Education Theory and Practice, 14(1), 81.

Coughlan, P., \& Coghlan, D. (2002). Action research for operation management. International Journal of Operations \& Production Management, 22(2), 220-240. http://dx.doi.org/10.1108/01443570210417515.

Dahms, M., \& Stentoft, D. (2008). Problem based learning in engineering education: a development option for Africa? In Proceedings of the 4th African Regional Conference on Engineering Education (ARCE-2008), Tanzania.

Dahms, M. L., Spliid, C. M., \& Nielsen, J. F. D. (2016). Teacher in a problem-based learning environment: Jack of all trades? European Journal of Engineering Education, 1-24. http://dx.doi.org/10.1080/03043797.2016.1271973.

Distlehorst, L., Dawson, E., Robbs, R., \& Barrows, H. (2005). Problem-based learning outcomes: the glass half-full. Academic Medicine, 80(3), 294-299. PMid:15734816. http://dx.doi.org/10.1097/00001888-200503000-00020.

Dochy, F., Segers, M., Van den Bossche, P., \& Gijbels, D. (2003). Effects of problem-based learning: a meta-analysis. Learning and Instruction, 13(5), 533-568. http://dx.doi.org/10.1016/S0959-4752(02)00025-7.

Duggan, K. (2012). Creating mixed model value streams: practical lean techniques for building to demand. London: CRC Press.

Fang, N., Cook, R., \& Hauser, K. (2006). Work in progress: an innovative interdisciplinary lean manufacturing course. In Proceedings of the 36th Annual Conference Frontiers in Education Conference (pp. 13-14), San Diego, CA, USA.

Felder, R., \& Silverman, L. (1988). Learning and teaching styles in engineering education. Engineering Education, 78(7), 674-681.

Felder, R., \& Soloman, B. (2004). Index of Learning Styles (ILS). Retrieved in 5 May 2016, from www2.ncsu.edu/unity/lockers/users/f/ felder/public/lLSpage.html

Felder, R., Felder, G., \& Dietz, E. (1998). A longitudinal study of engineering student performance and retention versus comparisons with traditionally-taught students. Journal of Engineering Education, 8744), 469-480. http://dx.doi.org/10.1002/j.2168-9830.1998. tb00381.x.

Fliedner, G., \& Mathieson, K. (2009). Learning lean: a survey of industry lean needs. Journal of Education for Business, 84(4), 194-199. http://dx.doi.org/10.3200/JOEB.84.4.194-199.

Flumerfelt, S., Kahlen, F., Alves, A., \& Siriban-Manalang, A. (2014). Lean Engineering Education: content and competency mastery. New York: ASME Press.

Galand, B., Frenay, M., \& Raucent, B. (2012). Effectiveness of problem-based learning in engineering education: a comparative study on three levels of knowledge structure. International Journal of Engineering Education, 28(4), 939-947.

Gijbels, D., Dochy, F., Van den Bossche, P., \& Segers, M. (2005). Effects of problem-based learning: a meta-analysis from the angle of assessment. Review of Educational Research, 75(1), 27-61. http://dx.doi.org/10.3102/00346543075001027. 
Hall, A., \& Holloway, L. (2008). Application of lean concepts to the teaching of lean manufacturing. In Proceedings of the 2007 American Society for Engineering Education Annual Conference \& Exposition, Honolulu, Hawaii.

Hasna, A. (2008). Problem based learning in engineering design. In Proceedings of SEFI 36th Annual Conference, European Society for Engineering Education, Aalborg, Denmark.

Hitt, J. (2010). Problem-based learning in engineering. West Point: Center for Teaching Excellence, United States Military Academy.

Hmelo-Silver, C. (2004). Problem-based learning: what and how do students learn? Educational Psychology Review, 16(3), $235-266$. http://dx.doi.org/10.1023/B:EDPR.0000034022.16470.f3.

Jaeger, M., \& Adair, D. (2014). The influence of students' interest, ability and personal situation on students' perception of a problem-based learning environment. European Journal of Engineering Education, 39(1), 84-96. http://dx.doi.org/10.1080/03043797.2013.833172.

Johnson, S. (2010). The value of inquiry in teaching lean process design. In Proceedings of the 2010 American Society for Engineering Education Annual Conference \& Exposition, Louisville, Kentucky.

Johnson, S., Gerstenfeld, A., Zeng, A., Ramos, B., \& Mishra, S. (2003). Teaching lean process design using a discovery approach. In Proceedings of American Society for Engineering Education Annual Conference \& Exposition, USA.

Jones, B., Epler, C., Mokri, P., Bryant, L., \& Paretti, M. (2013). The effects of a collaborative problem-based learning experience on students' motivation in engineering capstone courses. Interdisciplinary Journal of Problem-Based Learning, 7(2), 34-71. http:// dx.doi.org/10.7771/1541-5015.1344.

Kanigolla, D., Cudney, E., \& Corns, S. (2014). Enhancing engineering education using project-based learning for lean and six sigma. International Journal of Lean Six Sigma, 5(1), 45-61. http://dx.doi.org/10.1108/1JLSS-02-2013-0008.

Liker, J. (2004). The Toyota Way: 14 management principles from the world's greatest manufacturer. New York: McGraw-Hill.

Liker, J., \& Meier, D. (2006), The Toyota Way Field book: a practical guide for implementing Toyota's 4Ps. New York: McGraw-Hill.

Lima, R. M., Andersson, P. H., \& Saalman, E. (2017). Active Learning in Engineering Education: a (re)introduction. European Journal of Engineering Education, 42(1), 1-4. http://dx.doi.org/10.1080/03043797.2016.1254161.

Lonka, K., Nieminen, J., Sjoblom, F., \& Scheinin, P. (2005). Effects of problem-based learning in medicine. In Proceedings of 11th Biennial Conference of the European Association for Research on Learning and Instruction, Nicosia, Cyprus.

Mann, D. (2014). Creating a lean culture: tools to sustain lean conversions. London: CRC Press.

Mantri, A. (2014). Working towards a scalable model of problem-based learning instruction in undergraduate engineering education. European Journal of Engineering Education, 39(3), 282-299. http://dx.doi.org/10.1080/03043797.2013.858106.

Martins, C., Röse, A., Brognoli, A., Paes, M., \& Barddal, R. (2016). Kata improvement: developing abilities to solve problems and systematically learn at SESI Santa Catarina: a lean application at the work health and safe area. Journal of Lean Systems, 1(2), $107-121$.

McCrum, D. P. (2016). Evaluation of creative problem-solving abilities in undergraduate structural engineers through interdisciplinary problem-based learning. European Journal of Engineering Education, 1-17. http://dx.doi.org/10.1080/03043797.2016.1216089.

Miles, M., \& Hawks, V. (2006). Working with small companies in Cambodia to teach lean manufacturing principles to undergraduate students. In Proceedings of the 2006 American Society for Engineering Education Annual Conference \& Exposition, Kansas, Missouri.

Murman, E., McManus, H., \& Candido, J. (2007). Enhancing faculty competency in lean thinking bodies of knowledge. In Proceedings of the 3rd International CDIO Conference, Cambridge, Massachusetts.

Peter, G. (2010). Hands-on graduate courses in lean manufacturing (LM) emphasizing green and total productive maintenance (TPM). In Proceedings of American Society of Mechanical Engineers, 2010 International Mechanical Engineering Congress and Exposition (pp. 357-365), Fairfield, USA.

Rother, M., \& Shook, J. (2003). Learning to see: value stream mapping to add value and eliminate muda. Brooklyn: Lean Enterprise Institute.

Santos, D., Silva, C. (2015). Evaluation of students' general perceptions of problem-based learning in a computer engineering program in Brazil. Problems of Education in the 21st Century, 68, 74-83.

Shah, R., \& Ward, P. (2007). Defining and developing measures of lean production. Journal of Operations Management, 25(4), $785-805$. http://dx.doi.org/10.1016/j.jom.2007.01.019.

Sheppard, S., Macatangay, K., Colby, A., Sullivan, W., \& Shulman, L. (2008). Educating engineers: designing for the future of the field. Hoboken: Jossey-Bass.

Shingo, S. (1996). Quick changeover for operators: the SMED system. Massachusetts: SteinerBooks.

Shook, J. (2008). Managing to learn: using the A3 management process to solve problems, gain agreement, mentor and lead. New York: Lean Enterprise Institute.

Silva Junior, C., Fontenele, H., \& Silva, A. (2013). Estilos de ensino versus estilos de aprendizagem no processo de ensino aprendizagem: uma aplicação em transportes. Transportes, 21(2), 30-37. http://dx.doi.org/10.4237/transportes.v21i2.686.

Stier, K. (2003). Teaching lean manufacturing concepts through project-based learning and simulation. Journal of Information Technology, 19(4), 1-6.

Strobel, J., \& Van Barneveld, A. (2009). When is PBL more effective? A meta-synthesis of meta-analyses: comparing PBL to conventional classrooms. The Interdisciplinary Journal of Problem-Based Learning, 3(1), 44-58. http://dx.doi.org/10.7771/1541-5015.1046.

Torres, P., \& Stephens, M. (2005). Improving production performance through lean manufacturing techniques \& education in lean concepts. In Proceedings of the 2005 American Society for Engineering Education Annual Conference \& Exposition, Portland, Oregon.

Tortorella, G., \& Fogliatto, F. (2014). Method for assessing human resources management practices and organisational learning factors in a company under lean manufacturing implementation. International Journal of Production Research, 52(15), 4623-4645. http:// dx.doi.org/10.1080/00207543.2014.881577.

Tortorella, G., Viana, S., \& Fettermann, D. (2015). Learning cycles and focus groups: a complementary approach to the A3 thinking methodology. The Learning Organization, 22(4), 229-240. http://dx.doi.org/10.1108/TL0-02-2015-0008.

Tovar, E., \& Warshawsky, N. (2015). Use of a problem-based learning exercise to teach the lean 8-step problem-solving method. Nurse Educator, 40(2), 101-104. PMid:25695501. http://dx.doi.org/10.1097/NNE.0000000000000124. 
Wan, H., Liao, Y., \& Kuriger, G. (2012). Redesigning a lean simulation game for more flexibility and higher efficiency. In Proceedings of the 2012 American Society for Engineering Education Annual Conference \& Exposition, San Antonio, USA.

Warnock, J. N., \& Mohammadi-Aragh, J. (2016). Case study: use of problem-based learning to develop students' technical and professional skills. European Journal of Engineering Education, 41(2), 142-153. http://dx.doi.org/10.1080/03043797.2015.1040739.

White, H. (2001). Problem-based learning. Speaking of Teaching, 11(1), 1-7.

Womack, J., \& Jones, D. (2009). Lean solutions: how companies and customers can create value and wealth together. New York: Simon and Schuster.

Woods, D. (1996). Problem-based learning for large classes in chemical engineering. New Directions for Teaching and Learning, 1996(68), 91-99. http://dx.doi.org/10.1002/tl.37219966813.

Received: Oct. 10, 2016

Accepted: June 5, 2017 
Appendix A. Index of Learning Styles Questionnaire.

Full Name:

Postgraduate level application: ( ) Doctor; ( ) Master

Dedication: ( ) Full time; ( ) Part time

Previous experience with lean manufacturing: ( ) Yes; ( ) No

If Yes, how many years?

For each of the 44 questions below select either "a" or "b" to indicate your answer. Please choose only one answer for each question. If both "a" and "b" seem to apply to you, choose the one that applies more frequently.

1) 1 understand something better after 1
(a) try it out.
(b) think it through.

2) 1 would rather be considered
(a) realistic.
(b) innovative.

3) When 1 think about what 1 did yesterday, 1 am most likely to get
(a) a picture.
(b) words.

4) 1 tend to
(a) understand details of a subject but may be fuzzy about its overall structure.
(b) understand the overall structure but may be fuzzy about details.

5) When 1 am learning something new, it helps me to
(a) talk about it.
(b) think about it.

6) If 1 were a teacher, 1 would rather teach a course

(a) that deals with facts and real life situations.

(b) that deals with ideas and theories.

7) 1 prefer to get new information in

(a) pictures, diagrams, graphs, or maps.

(b) written directions or verbal information.

8) Once 1 understand
(a) all the parts, 1 understand the whole thing.
(b) the whole thing, 1 see how the parts fit.

9) In a study group working on difficult material, 1 am more likely to
(a) jump in and contribute ideas.
(b) sit back and listen.

10) 1 find it easier
(a) to learn facts.
(b) to learn concepts.

11) In a book with lots of pictures and charts, 1 am likely to
(a) look over the pictures and charts carefully.
(b) focus on the written text.

12) When 1 solve math problems

(a) 1 usually work my way to the solutions one step at a time.

(b) 1 often just see the solutions but then have to struggle to figure out the steps to get to them.

13) In classes 1 have taken

(a) 1 have usually gotten to know many of the students.

(b) 1 have rarely gotten to know many of the students. 
14) In reading nonfiction, 1 prefer

(a) something that teaches me new facts or tells me how to do something.

(b) something that gives me new ideas to think about.

15) 1 like teachers

(a) who put a lot of diagrams on the board.

(b) who spend a lot of time explaining.

16) When l'm analyzing a story or a novel

(a) 1 think of the incidents and try to put them together to figure out the themes.

(b) 1 just know what the themes are when 1 finish reading and then 1 have to go back and find the incidents that demonstrate them.

17) When 1 start a homework problem, 1 am more likely to
(a) start working on the solution immediately.
(b) try to fully understand the problem first.

18) 1 prefer the idea of
(a) certainty.
(b) theory.

19) 1 remember best
(a) what 1 see.
(b) what 1 hear.

20) It is more important to me that an instructor
(a) lay out the material in clear sequential steps.
(b) give me an overall picture and relate the material to other subjects.

21) 1 prefer to study
(a) in a study group.
(b) alone.

22) 1 am more likely to be considered
(a) careful about the details of my work.
(b) creative about how to do my work.

23) When 1 get directions to a new place, 1 prefer
(a) a map.
(b) written instructions.

24) 1 learn

(a) at a fairly regular pace. If 1 study hard, l'll "get it."

(b) in fits and starts. l'll be totally confused and then suddenly it all "clicks."

25) 1 would rather first
(a) try things out.
(b) think about how l'm going to do it.

26) When 1 am reading for enjoyment, 1 like writers to
(a) clearly say what they mean.
(b) say things in creative, interesting ways.

27) When 1 see a diagram or sketch in class, 1 am most likely to remember
(a) the picture.
(b) what the instructor said about it.

28) When considering a body of information, 1 am more likely to
(a) focus on details and miss the big picture.
(b) try to understand the big picture before getting into the details.

29) 1 more easily remember

(a) something 1 have done.

(b) something 1 have thought a lot about. 
30) When 1 have to perform a task, 1 prefer to
(a) master one way of doing it.
(b) come up with new ways of doing it.

31) When someone is showing me data, 1 prefer
(a) charts or graphs.
(b) text summarizing the results.

32) When writing a paper, 1 am more likely to
(a) work on (think about or write) the beginning of the paper and progress forward.
(b) work on (think about or write) different parts of the paper and then order them.

33) When 1 have to work on a group project, 1 first want to
(a) have "group brainstorming" where everyone contributes ideas.
(b) brainstorm individually and then come together as a group to compare ideas.

34) 1 consider it higher praise to call someone
(a) sensible.
(b) imaginative.

35) When 1 meet people at a party, 1 am more likely to remember
(a) what they looked like.
(b) what they said about themselves.

36) When 1 am learning a new subject, 1 prefer to

(a) stay focused on that subject, learning as much about it as 1 can.

(b) try to make connections between that subject and related subjects.

37) 1 am more likely to be considered
(a) outgoing.
(b) reserved.

38) 1 prefer courses that emphasize
(a) concrete material (facts, data).
(b) abstract material (concepts, theories).

39) For entertainment, 1 would rather
(a) watch television.
(b) read a book.

40) Some teachers start their lectures with an outline of what they will cover. Such outlines are
(a) somewhat helpful to me.
(b) very helpful to me.

41) The idea of doing homework in groups, with one grade for the entire group,
(a) appeals to me.
(b) does not appeal to me.

42) When 1 am doing long calculations,

(a) 1 tend to repeat all my steps and check my work carefully.

(b) 1 find checking my work tiresome and have to force myself to do it.

43) 1 tend to picture places 1 have been
(a) easily and fairly accurately.
(b) with difficulty and without much detail.

44) When solving problems in a group, 1 would be more likely to
(a) think of the steps in the solution process.
(b) think of possible consequences or applications of the solution in a wide range of areas.

Adapted from Felder \& Soloman (2004). 